\title{
Evaluation of Physicochemical Properties and Metallic Contents in Vegetables Irrigated with Water from Different Sources
}

\author{
Faiza Hassan', Faisal Mehmood', Qamar uz Zaman², Dure Najaf Iqbal', \\ Roeya Rehman', Farheen Aslam ${ }^{3}$, Sadia Sagar ${ }^{4}$, Nasir Masood ${ }^{5}$, \\ Arif Nazir ${ }^{1}$, Munawar Iqbal ${ }^{1 *}$ \\ ${ }^{1}$ Department of Chemistry, The University of Lahore, Lahore, Pakistan \\ ${ }^{2}$ Department of Environmental Science, The University of Lahore, Lahore, Pakistan \\ ${ }^{3}$ Department of Biotechnology, Lahore College for Women University, Lahore, Pakistan \\ ${ }^{4}$ Department of Physics, The University of Lahore, Lahore, Pakistan \\ ${ }^{5}$ Department of Environmental Sciences, COMSATS University Islamabad, Sub Campus Vehari, Punjab, Pakistan
}

Received: 11 January 2020

Accepted: 20 July 2020

\begin{abstract}
This study focuses on the assessment of health risk potential by quantifying some selected metals ( $\mathrm{Cd}, \mathrm{Cr}, \mathrm{Fe}, \mathrm{Cu}, \mathrm{Mn}, \mathrm{Zn}, \mathrm{Ni}, \mathrm{Pb})$ in vegetables and soil irrigated with different sources of water. The physicochemical parameters of irrigating water were within the safe limits except for SAR in sewage water $(18.723 \mathrm{mg} / \mathrm{kg})$ and industrial wastewater $(40.332 \mathrm{mg} / \mathrm{kg})$. The $\mathrm{Mn}(19 \mathrm{mg} / \mathrm{kg})$ was higher than the safe limit in vegetable and soil irrigated with tube well water. The sewage water irrigated vegetable had high level of cadmium $(1.557 \mathrm{mg} / \mathrm{kg})$, lead $(2.307 \mathrm{mg} / \mathrm{kg})$ and chromium $(3.566 \mathrm{mg} / \mathrm{kg})$ than safe limits. The canal water had high level of cadmium $(0.286 \mathrm{mg} / \mathrm{kg})$ and lead $(0.569 \mathrm{mg} / \mathrm{kg})$. The vegetable irrigated with tube well water was best for human health while vegetable irrigated with sewage water, canal water, and industrial wastewater was of poor quality and unfit for human health due to high level of toxic metals.
\end{abstract}

Keywords: heavy metals, wastewater, vegetables, soil, pollution

\section{Introduction}

Rapid industrial revolution and urbanization pollute the soil and water sources by releasing the metallic and toxic chemicals [1-3]. Due to the lack of proper

*e-mail: chemuaf@gmail.com sewerage system, the wastewater from the houses, hotels, markets, hospitals and industries is directly released into the water channels $[4,5]$. It is estimated that $10 \%$ world population irrigate food crops with wastewater. Developing countries use the industrial and municipal sewage water for irrigation [6, 7]. Undoubtedly, wastewater contain plant nutrients which make up the deficiency of fertilizers. On the other hand, it has health and environmental risks due to the 
presence of synthetic chemicals, pathogens and heavy metals [8].

The most important parts of human diet are the vegetables because they contain protein, vitamins, minerals, carbohydrates and trace metals [8-10]. Vegetable crops are at high risks for uptake of toxic heavy metals on irrigation with polluted wastewater [11]. Plants have the capacity to accumulate heavy metals from the contaminated soils. Plants use various ways including rhizo-filtration, phytoextraction and phyto-stabilization to eliminate the contaminants from the water and soil as well [12]. Heavy metals cause wilting of leaves, enzyme system inactivation, decrease the plant height, and affect photosynthesis and respiration [13]. The plants uptake the toxic metals via roots and it is transferred to human through food chain. Toxic heavy metals cause dangerous effect in the living ones due to nonbiodegradable nature [14]. Moreover, the majority of heavy metals are poisonous due to their water solubility and cause various diseases [15] by damaging immune system, malnutrition and gastrointestinal cancer [16]. The objective of this research work is to assess the potential of metal toxicity of some selected metals like $\mathrm{Cd}, \mathrm{Cr}, \mathrm{Fe}, \mathrm{Cu}, \mathrm{Mn}, \mathrm{Zn}, \mathrm{Ni}$ and $\mathrm{Pb}$ in vegetable (Abelmoschus esculentus) and soil using different water sources.

\section{Materials and Methods}

Samples of soil $(0.5 \mathrm{~kg})$ were collected with the help of pre-cleaned sampler from the four different locations (Burewala, Vehari). The sampling site was selected based on different irrigation sources (tube well water, canal water, sewage water and industrial wastewater). The samples of soil were dried under shade and then placed in oven at $72^{\circ} \mathrm{C}$ for $6 \mathrm{~h}$. These dried samples were ground to fine powder using pestle mortar, sieved through $2 \mathrm{~mm}$ mesh size and packed in pre washed polythene bags. Samples of water were collected (500 $\mathrm{mL}$ ) with the help of water sampler from the depth of $10-15 \mathrm{~cm}$ of water surface. These samples were stored in cleaned plastic bottles and $3 \mathrm{~mL}$ of conc. $\mathrm{HNO}_{3}$ was added in each sample bottle to prevent microbial activity. Vegetable samples $(0.5 \mathrm{~kg})$ were collected from the above-mentioned sites and washed using de-ionized water to remove the dust particles. These samples were placed under shade for 7 days and oven dried at $73^{\circ} \mathrm{C}$ for 3 days. The samples were ground to fine powder, passed through $1 \mathrm{~mm}$ sieve and stored in cleaned polythene bags.

$1 \mathrm{~g}$ soil sample was weighed after mixing and $5 \mathrm{~mL}$ aqua regia was added in it. It was digested on the hot plate under fume hood unless the fumes color changed from brown to off white. After cooling, $15 \mathrm{~mL}$ of de-ionized water was added, filtered off the sample and made up filtrate to $50 \mathrm{~mL}$ by distilled water. $1 \mathrm{~g}$ sample of vegetable was digested on the hot plate by adding the
$5 \mathrm{~mL}$ mixture of sulfuric acid $\left(\mathrm{H}_{2} \mathrm{SO}_{4}\right)$ and hydrogen peroxide $\left(\mathrm{H}_{2} \mathrm{O}_{2}\right)$ with 1:2 ratio. The digestion had been continued till the solution became clear. Atomic absorption spectrophotometer was used to determine quantity of heavy metals in the samples using the respective hallow cathode lamp.

\section{Results and Discussion}

The rapid industrial revolution and urbanization have a great impact on the quality of the environment [17]. The selected toxic metals like $\mathrm{Ni}, \mathrm{Cd}, \mathrm{Cr}, \mathrm{Pb}$ $\mathrm{Cu}, \mathrm{Fe}, \mathrm{Zn}$ and $\mathrm{Mn}$ were observed in tube well water irrigated vegetables. All these values were found lower than permissible limits [18]. All the data is given in Table 1. These results are found in accordance to the previous report from Bahawalpur Pakistan [19]. The similar reports was also recorded by Attock and Mardan [11, 13]. The mean content of these metals in tube well water irrigated soil were recorded as $0.108,0.004,0.006,0.180,6.350,16.272,4.330$ and $19.004 \mathrm{mgkg}^{-1}$ respectively and are within the permissible limits. All these values were lower than safe limits except Mn, but the other researcher found these results less than permissible limits [13, 19]. The average values of physio-chemical parameters like $\mathrm{pH}, \mathrm{EC}, \mathrm{SAR}, \mathrm{Na}, \mathrm{Ca}^{2+} \mathrm{Mg}, \mathrm{HCO}_{3}^{-1}, \mathrm{CO}_{3}^{-2}$ and $\mathrm{Cl}^{-1}$ of tube well water was $7.141,2.504 \mu \mathrm{S} / \mathrm{cm}, 15.594 \mathrm{meq} / \mathrm{L}$, $8.850,9.388,11.041,3.423$ and $1.542 \mathrm{mgL}^{-1}$ respectively. These values were observed lower than safe limits and were found similar to the previous report.

These selected metals were also observed in sewage water irrigated vegetables. The level of $\mathrm{Pb}, \mathrm{Cr}$ and $\mathrm{Cd}$ are found more than safe limits in the current study. Previous study reports the concentration of $\mathrm{Pb}$ a little higher than the safe limit [20]. At higher concentrations than the safe limits causes impairment kidney, nervous cancer, liver, cardiovascular, poor immune system, disabilities of malnutrition, growth retardation and gastrointestinal cancer [11]. Previous studies report that contaminated water irrigated vegetables had higher metal contents than uncontaminated water treatment $[19,21]$.

The mean contents of metals in sewage water irrigated soil are 20.478, 2.283, 4.080, 9.567, 22.958, $353.120,20.270$ and $72.710 \mathrm{mgkg}^{-1}$ respectively. The Cd and $\mathrm{Mn}$ contents crossed the safe limits in current study [19]. Previous study reports the higher metals content in sewage water soil than freshwater irrigated soil [21]. The mean values of physio-chemical parameters in sewage water are $7.652,3.133 \mu \mathrm{S} / \mathrm{cm}, 18.723 \mathrm{meq} / \mathrm{L}, 8.933$, $8.783,12.112,2.558$ and $1.529 \mathrm{mgL}^{-1}$ respectively [22]. The value of SAR crossed the safe limit in the current study. The high level of SAR causes to minimize the permeability of the soil [23].

The canal water vegetable has the mean values of metals as $0.234,0.286,0.366,0.569,0.216,1.174$, 1.231 and $0.884 \mathrm{mgkg}^{-1}$ respectively. In these samples 
Table 1. Metal contents in treated vegetables and soil and physicochemical parameters (Mean \pm SE).

\begin{tabular}{|c|c|c|c|c|c|}
\hline \multicolumn{6}{|c|}{ Vegetables } \\
\hline Metals & Tube well water & Sewage water & Canal water & Industrial water & Permissible limits $(\mathrm{mg} / \mathrm{kg})$ \\
\hline $\mathrm{Ni}$ & $0.038 \pm 0.269$ & $5.284 \pm 0.171$ & $0.234 \pm 0.205$ & $2.192 \pm 0.045$ & 67.00 \\
\hline $\mathrm{Cd}$ & $0.001 \pm 0.433$ & $1.557 \pm 0.123$ & $0.286 \pm 0.110$ & $0.046 \pm 0.515$ & 0.10 \\
\hline $\mathrm{Pb}$ & $0.034 \pm 0.167$ & $2.307 \pm 0.134$ & $0.569 \pm 0.109$ & $0.626 \pm 0.533$ & 0.30 \\
\hline $\mathrm{Cr}$ & $0.035 \pm 0.145$ & $3.566 \pm 0.141$ & $0.366 \pm 0.137$ & $0.820 \pm 0.124$ & 2.30 \\
\hline $\mathrm{Cu}$ & $0.016 \pm 0.333$ & $2.914 \pm 0.040$ & $0.216 \pm 0.116$ & $0.714 \pm 0.061$ & 73.00 \\
\hline $\mathrm{Zn}$ & $0.011 \pm 0.430$ & $1.109 \pm 0.023$ & $1.231 \pm 0.037$ & $0.406 \pm 0.147$ & 100.00 \\
\hline $\mathrm{Fe}$ & $0.063 \pm 0.176$ & $1.234 \pm 0.036$ & $1.174 \pm 0.054$ & $2.466 \pm 0.132$ & 425.00 \\
\hline $\mathrm{Mn}$ & $0.016 \pm 0.328$ & $1.743 \pm 0.195$ & $0.884 \pm 0.047$ & $0.511 \pm 0.163$ & 6.610 \\
\hline \multicolumn{6}{|c|}{ Soil } \\
\hline $\mathrm{Ni}$ & $0.108 \pm 0.186$ & $20.478 \pm 0.029$ & $0.854 \pm 0.086$ & $39.146 \pm 0.015$ & 50 \\
\hline $\mathrm{Cd}$ & $0.004 \pm 0.303$ & $2.283 \pm 0.128$ & $0.410 \pm 0.044$ & $4.997 \pm 0.030$ & 0.31 \\
\hline $\mathrm{Pb}$ & $0.180 \pm 0.103$ & $9.567 \pm 0.078$ & $0.900 \pm 0.062$ & $11.316 \pm 0.004$ & 100 \\
\hline $\mathrm{Cr}$ & $0.006 \pm 0.270$ & $4.080 \pm 0.014$ & $0.557 \pm 0.090$ & $5.776 \pm 0.104$ & 8.0 \\
\hline $\mathrm{Cu}$ & $6.350 \pm 0.013$ & $22.958 \pm 0.046$ & $0.927 \pm 0.038$ & $40.014 \pm 0.024$ & 100 \\
\hline $\mathrm{Zn}$ & $4.330 \pm 0.39$ & $20.270 \pm 0.023$ & $1.353 \pm 0.004$ & $35.850 \pm 0.017$ & 300 \\
\hline $\mathrm{Fe}$ & $16.272 \pm 0.008$ & $353.120 \pm 0.025$ & $1.622 \pm 0.026$ & $312.597 \pm 0.012$ & 50000 \\
\hline $\mathrm{Mn}$ & $19.004 \pm 0.009$ & $72.710 \pm 0.015$ & $1.604 \pm 0.144$ & $69.914 \pm 0.032$ & 12 \\
\hline \multicolumn{6}{|c|}{ Physicochemical parameters } \\
\hline $\mathrm{pH}$ & $7.141 \pm 0.011$ & $7.652 \pm 0.007$ & $7.902 \pm 0.014$ & $8.277 \pm 0.020$ & 9.2 \\
\hline $\mathrm{EC}$ & $2.504 \pm 0.209$ & $3.133 \pm 0.044$ & $0.258 \pm 0.196$ & $280.111 \pm 0.092$ & $1500 \mu \mathrm{S} / \mathrm{cm}$ \\
\hline SAR & $15.594 \pm 0.092$ & $18.723 \pm 0.008$ & $2.436 \pm 0.162$ & $40.332 \pm 0.037$ & $18 \mathrm{meq} / \mathrm{L}$ \\
\hline $\mathrm{Na}$ & $8.850 \pm 0.034$ & $8.933 \pm 0.016$ & $1.518 \pm 0.078$ & $7.363 \pm 0.206$ & 200ppm \\
\hline $\mathrm{Ca}, \mathrm{Mg}$ & $9.388 \pm 0.042$ & $8.783 \pm 0.028$ & $4.790 \pm 0.025$ & $2.024 \pm 1.060$ & $500 \mathrm{ppm}$ \\
\hline $\mathrm{HCO}_{3}^{-1}$ & $11.041 \pm 0.013$ & $12.112 \pm 0.005$ & $2.971 \pm 0.114$ & $17.092 \pm 0.064$ & 600 ppm \\
\hline $\mathrm{CO}_{3}^{-2}$ & $3.423 \pm 0.074$ & $2.558 \pm 0.020$ & $0.477 \pm 0.030$ & $14.909 \pm 0.239$ & $180 \mathrm{ppm}$ \\
\hline $\mathrm{Cl}$ & $1.542 \pm 0.109$ & $1.529 \pm 0.036$ & $0.251 \pm 0.149$ & $12.200 \pm 0.018$ & $600 \mathrm{ppm}$ \\
\hline
\end{tabular}

the level of $\mathrm{Cd}$ and $\mathrm{Pb}$ crossed the safe limits. Overall, all the metals except $\mathrm{Pb}$ were under the safe limit reported in previous studies [20]. It may also lead to the carcinogenic, vomiting, cramps, loss of consciousness, respiratory difficulties, nausea, liver dysfunction, teratogenic and neurotoxin [19]. The mean contents of these metals in canal water irrigated soil are 0.854 , $0.410,0.557,0.900,0.927,1.622,1.353$ and $1.604 \mathrm{mgkh}^{-1}$ respectively [20]. The mean values of physio-chemical parameters in canal water were $7.902,0.258 \mu \mathrm{S} / \mathrm{cm}$, $2.436 \mathrm{meq} / \mathrm{L}, 1.518,4.790,2.971,0.477$ and $0.251 \mathrm{mgL}^{-1}$ respectively. All these parameters were found under the safe limits [24].

The industrial watered vegetable has metal contents as $2.192,0.046,0.820,0.626,0.714,2.466,0.406$ and $0.511 \mathrm{mgkg}^{-1}$ respectively. These metals were found lower than safe limits except $\mathrm{Pb}$, it crossed the safe limit in the current study and recorded these metals higher than safe limits [13]. The content of $\mathrm{Pb}$ may be increased by the incineration of waste material. For instance, in children exposure of lead causes lower IQ, hyperactivity, mental deterioration, shortened attention span. Lead has significant risk in children under six years of age. In adults, $\mathrm{Pb}$ causes anorexia, loss of memory, failure of reproduction, irritation, insomnia, nausea, decreased reaction time and producing tumors [25]. The mean content of these metals in industrial water irrigated soil are 39.146, 4.997, 5.776, 11.316, $40.014,312.597,35.850$ and $69.914 \mathrm{mgkg}^{-1}$ respectively. In the industrial water soil the content of $\mathrm{Cd}$ and $\mathrm{Mn}$ crossed the safe limits and the other metals were under the safe limits [13]. Cd is generated from fossil fuels, 
lead refining, motor oil, by-product of zinc and sewage sludge [26]. When water with high level of SAR is used to irrigate the soil, it reduces the permeability of soil. Previous research in Pakistan had also reported the same results [27].

\section{Concluions}

Vegetable irrigated with tube well water has low level of metals than permissible limits. On the other hand, sewage sewage water irrigated vegetable has high level of $\mathrm{Pb}, \mathrm{Cr}$ and $\mathrm{Cd}$ than safe limits, the canal water irrigated vegetable has slightly higher level of $\mathrm{Pb}$ and $\mathrm{Cd}$ than safe limits and industrial water vegetable has high level of $\mathrm{Pb}$ than permissible limits. Sewage water vegetable was the found the most toxic but tube well water vegetable was found the best for human health. It is suggested to use tube well water for irrigation purposes in the studied area.

\section{Conflict of Interest}

The authors declare no conflict of interest.

\section{References}

1. NOUREN S., SARWAR M., MUHI-UD-DIN G., YAMEEN M., BHATTI H.N., SOOMRO G.A., SULEMAN M., BIBI I., KAUSAR A., NAZIR A. Sweet Lime-Mediated Decolorization of Textile Industry Effluents. Pol. J. Environ. Stud. 28 (1), 283, 2019.

2. JABEEN S., ALI S., NADEEM M., ARIF K., QURESHI N., SHAR G.A., SOOMRO G.A., IQBAL M., NAZIR A., SIDDIQUA U.H. Statistical Modeling for the Extraction of Dye from Natural Source and Industrial Applications. Pol. J. Environ. Stud. 28 (4), 2145, 2019.

3. HUSSAIN A., AHMAD M.N., JALAL F., YAMEEN M., FALAK S., NOREEN S., NAZ S., NAZIR A., IFTIKHAR S., SOOMRO G.A., IQBAL M. Investigating the Antibacterial Activity of POMA Nanocomposites. Pol. J. Environ. Stud. 28 (6), 4191, 2019.

4. AKPONIKPÈ P.I., WIMA K., YACOUBA H., MERMOUD A. Reuse of domestic wastewater treated in macrophyte ponds to irrigate tomato and eggplant in semi-arid West-Africa: Benefits and risks. Agric. Water Manage. 98 (5), 834, 2011.

5. FAIZAN S., KAUSAR S., AKHTAR N. Influence of wastewater application and fertilizer use on growth, photosynthesis, nutrient homeostatis, yield and heavy metal accumulation in okra (Abelmoschus esculentus L. Moench). Pak. J. Biol. Sci. 17 (5), 630, 2014.

6. PERVEEN S., SAMAD A., NAZIF W., SHAH S. Impact of sewage water on vegetables quality with respect to heavy metals in Peshawar, Pakistan. Pak. J. Bot. 44 (6), 1923, 2012

7. ANWAR S., NAWAZ M.F., GUL S., RIZWAN M., ALI S., KAREEM A. Uptake and distribution of minerals and heavy metals in commonly grown leafy vegetable species irrigated with sewage water. Environ. Monitor. Assess. 188 (9), 541, 2016.
8. AHMED M. ABU-DIEF, ZIKRY M.M. adsorption of the Heavy Metal Ions onto Bio sorbents: A review. Int. J. Nanomater. Chem. 4 (3), 27, 2018.

9. IBISI N.E., ASOLUKA C.A. Use of agro-waste (Musa paradisiaca peels) as a sustainable biosorbent for toxic metal ions removal from contaminated water. Chem. Int. 4 (1), 52, 2018

10. THAKUR R., TARAFDER P.K., JHA R.R. Micellemediated extraction of cobalt and its spectrophotometric determination in rocks, soils, sediments and sea-bed polymetallic nodules. Chem. Int. 5 (1), 109, 2015.

11. HUSSAIN A., ALAMZEB S., BEGUM S. Accumulation of heavy metals in edible parts of vegetables irrigated with waste water and their daily intake to adults and children, District Mardan, Pakistan. Food Chem. 136 (3-4), 1515, 2013.

12. AHMAD K., IBRAHIM M., KHAN Z.I., RIZWAN Y., EJAZ A., FARDSOUS A., GONDAL S., LEE D.J., AL-YEMENI M. Effect of sewage water on mineral nutritive potential of six fodder species grown under semiarid conditions. Sau. J. Biol. Sci. 18 (4), 317, 2011.

13. BASHIR M., KHALID S., RASHID U., ADREES M., IBRAHIM M., ISLAM M.S. Assessment of Selected Heavy Metals Uptake from Soil by Vegetation of Two Areas of District Attock, Pakistan. Asian J. Chem. 26 (4), 1063, 2014.

14. SHAHID M., DUMAT C., POURRUT B., ABBAS G., SHAHID N., PINELLI E. Role of metal speciation in leadinduced oxidative stress to Vicia faba roots. Rus. J. Plant Physiol. 62 (4), 448, 2015.

15. LIN H.-J., SUNG T.-I., CHEN C.-Y., GUO H.-R. Arsenic levels in drinking water and mortality of liver cancer in Taiwan. J. Hazard. Mater. 262, 1132, 2013.

16. ITOH H., IWASAKI M., SAWADA N., TAKACHI R., KASUGA Y., YOKOYAMA S., ONUMA H., NISHIMURA H., KUSAMA R., YOKOYAMA K. Dietary cadmium intake and breast cancer risk in Japanese women: a case-control study. Int. J. Hyg. Environ. Health 217(1), 70, 2014.

17. SARWAR N., IMRAN M., SHAHEEN M.R., ISHAQUE W., KAMRAN M.A., MATLOOB A., REHIM A., HUSSAIN S. Phytoremediation strategies for soils contaminated with heavy metals: Modifications and future perspectives. Chemosphere 171, 710, 2017.

18. MUNIR A., SULTANA B., BASHIR A., GHAFFAR A., MUNIR B., SHAR G.A., NAZIR A., IQBAL M. Evaluation of Antioxidant Potential of Vegetables Waste. Pol. J. Environ. Stud. 27 (2), 947, 2018.

19. IQBAL H.H., TASEER R., ANWAR S., QADIR A., SHAHID N. Human health risk assessment: Heavy metal contamination of vegetables in Bahawalpur, Pakistan. Bull. Environ. Stud. 1 (1), 10, 2016.

20. KHAN Z.I., AHMAD K., AKRAM N.A., MEHMOOD N., YASMEEN S. Heavy metal contamination in water, soil and a potential vegetable garlic (Allium sativum L.) in Punjab, Pakistan. Pak. J. Bot. 49 (2), 547, 2017.

21. JAN F.A., ISHAQ M., KHAN S., IHSANULLAH I., AHMAD I., SHAKIRULLAH M. A comparative study of human health risks via consumption of food crops grown on wastewater irrigated soil (Peshawar) and relatively clean water irrigated soil (lower Dir). J. Hazard. Mater. 179 (1-3), 612, 2010.

22. WHO. Guidelines for drinking-water quality, health criteria and other supporting information. 1996.

23. SIDDIQUE A., HASSAN A., KHAN S.R., INAYAT A., NAZIR A., IQBAL M. Appraisal of heavy metals and 
nutrients from phosphate rocks, Khyber Pakhtunkhwa, Pakistan. Chem. Int. 4 (1), 1, 2018.

24. ALI K., AKHTAR N., SHUAIB M., ALI S., GHAFFAR A., SHAH M., KHAN A., HUSSAIN F., KHAN Z., KALEEM I., NAZIR A., IQBAL M. Impact of Urbanization on Vegetation: a Survey of Peshawar, Pakistan. Pol. J. Environ. Stud. 28 (4), 2523, 2019.

25. QURESHI N., EHTISHAM-UL-HAQUE S., ABBAS M., YAMEEN M., FAROOQ AZHAR M., MAHMOUDI G., NAZIR A, IQBAL M. Synthesis of fluorescent di-dansyl substituted ethoxy compound: A selective sensor for antimony and thallium metals detection. J. Mater. Res. Technol. 8 (1), 1576, 2019.

26. BHAGURE G.R., MIRGANE S. Heavy metal concentrations in groundwaters and soils of Thane Region of Maharashtra, India. Environ. Monitor. Assess. 173 (1-4), 643, 2011.

27. CHAUDHRY H., NISAR N., MEHMOOD S., IQBAL M., NAZIR A., YASIR M. Indian Mustard Brassica juncea efficiency for the accumulation, tolerance and translocation of zinc from metal contaminated soil. Biocatal. Agric. Biotechnol. 23, 101489, 2020. 